\title{
A faunistic study on the hoverflies (Diptera: Syrphidae) from West Azarbaijan province, Iran
}

With 1 map

NaJMEh SAMin ${ }^{1}$, Hamid SAKEnIN ${ }^{2}$ and JANINA BENNEWICZ ${ }^{3}$

${ }^{1}$ Young Researchers and Elite Club, Science and Research Branch, Islamic Azad University, Tehran, Iran. - n_samin63@yahoo.com
${ }^{2}$ Department of Plant Protection, Qaemshahr Branch, Islamic Azad University, Mazandaran, Iran. - hchelave@yahoo.com
${ }^{3}$ Department of Zoology, Bydgoszcz University of Technology and Life Sciences, Kordeckiego 20, 85-225 Bydgoszcz, Poland. -
jbennewicz@utp.edu.pl
Published on 2015-12-21

\section{Summary}

Hoverflies (Diptera: Syrphidae) play an efficient role in biological control of agricultural pests and also in pollination. This paper deals with the faunistic data on Syrphidae from West Azarbaijan province, northwestern Iran. In total 34 species from 21 genera and 2 subfamilies (Milesiinae and Syrphinae) were collected and determined.

\section{Key words}

Diptera, Syrphidae, hoverflies, fauna, West Azarbaijan, Iran

\section{Zusammenfassung}

Schwebfliegen (Diptera: Syrphidae) spielen eine bedeutende Rolle in der biologischen Bekämpfung von landwirtschaftlichen Schädlingen sowie als Bestäuber. Hier präsentieren wir faunistische Daten über Syrphidae aus der West Azarbaijan Provinz, Nordwest-Iran. Insgesamt wurden 34 Arten aus 21 Gattungen und 2 Unterfamilien (Milesiinae und Syrphinae) gesammelt und determiniert.

\section{Introduction}

Syrphidae with 200 genera and more than 6000 species worldwide is one of the most diverse families in order Diptera (StubBs \& Falk 2002). Larvae of syrphid flies have an efficient role in biological control of aphids (Hemiptera: Aphididae). Also some of the members of the family are common pollinators which are active wherever flowers are found, being absent only in truly arid areas and the Polar Regions (FAEGRI \& VAN Der PiJl 1979; Kevan \& BAKer 1983). An important function of natural refugia is the occurrence not only

of various phytophages, but also their predators and parasites (OlszaK 1999; BenNewicz 2011). It is also assumed that the specialized syrphid predators play a major role in limiting aphid populations (BUGG 1993; Brown 2004; Speight 2011). Habitats rich in flowering plants, constituting a source of food for adult aphidophagous syrphids, are of great importance for these insects, not to mention other beneficial organisms (Frank 1999; CANDEMir \& Kara 2003). Many species, being regular visitors of flowers, are important pollina- 
tors of various plants including vegetables, fruit trees (e.g. Asteraceae, Brassicaceae, and Rosaceae) and flowering plants (Kevan \& BaKer 1983; Simic \& GlumaC 1987; SsYMANK et al. 2008).

The fauna of Iranian Syrphidae has been studied well and several papers have been published recently (e.g. Khiaban etal. 1998; Dousti 1999; Gharali et al. 2000; Pashae Rad et al. 2002; Khiaban \& Adim 2002; Alichi et al. 2002; Goldasteh et al. 2002; SADEghI et al. 2002; SAdeghi 2003; Kamangar et al. 2004; Golmohammadi \& Khiaban 2004; Gilasian 2005; Kamangar et al. 2006; Motamedi Nia \& Wyatt 2006; SAdeghi 2008; Bedoreh et al. 2008; Hosseini \& SADEghi 2008; GHAhari et al. 2008a, b; SAKenin Chelav et al. 2008; Khaghaninia 2010; Ehteshamnia et al. 2010; KHAGHANinia et al. 2010a, b, c, d; JABBARI 2011; Khaghaninia 2011; Khaghaninia et al. 2011; Gilasian \& Sorokina 2011; Naderloo et al. 2011; Khaghaninia \& Shakeryari 2012; Shakeryari \& Khaghaninia 2012; Bedoreh \& ANSARI POUR 2012; Khaghaninia et al. 2012a, b, 2014; Shakeryari et al. 2012; KaZerani et al. 2012; Khaghaninia \& HosseinI 2013; Mohammadi \& Khaghaninia 2013; Vosughian et al. 2013; Khaghaninia 2014; Gharali \& Reemer 2014; Khaghaninia \& Kazerani 2014; Hosseini \& Khaghaninia 2014, 2015; Khosravian et al. 2015; Mengual et al. 2015). Checklists of Iranian hoverflies were prepared by Peck (1988), Modarres Awal (1997), Dousti \& Hayat (2006) and Kazerani et al. (2013). In this paper, the syrphid fauna of West Azarbaijan province (located in North West of Iran, bordering with Turkey, Iraq and Armenia, and the provinces of East Azarbaijan, Zanjan and Kurdistan - fig. 1) is dealt with. It covers an area of $43,660 \mathrm{~km}^{2}$, and the climate is largely influenced by the rainy winds of the Atlantic Ocean and Mediterranean. According to existing meteorological data, local temperatures vary within the province. The highest temperature reaches $34^{\circ} \mathrm{C}$ in July, and the lowest temperature is $-16^{\circ} \mathrm{C}$ in January.

\section{Materials and Methods}

The specimens of this research were collected by sweeping net and Malaise traps in different regions of West Azarbaijan province $\left(37.5528^{\circ} \mathrm{N} 45.0759^{\circ} \mathrm{E}\right)$ during spring and summer of 2012-2013. The sampled regions were Khoy, Ourmieh, Maku, Mahabad, Oshnavieh, Salmas, and Miandoab, and the collected materials were placed in a desiccator (having water at its bottom) for about $24 \mathrm{~h}$ in order to soak and soften them. Thereafter, they were pinned and their wings and legs set on appropriate setting boards to facilitate morphological studies and the others were put into tubes filled with $70 \%$ alcohol. In addition to the sampled materials, the insect collection of Islamic Azad University was checked and the data are used in this paper. The specimens were examined with a stereomicroscope and identified using the relevant literature such as BEZzI (1966), BEI-BIENKo (1988), Papp \& Darvas (1997, 1998, 2000), Stubbs \& Falk (2002), van Veen (2004), Lyneborg \& BarkeMeyer (2005) and Speight (2011). The materials are preserved in the collections of the authors. The distribution data of Syrphidae mostly suggested by SPEIGHT (2011) have been followed.

\section{Results}

In total 34 syrphid species from 21 genera and 2 subfamilies, Milesiinae and Syrphinae were collected and identified. The list of species is given below with distribution data.

\section{Subfamily Milesiinae \\ Genus Cheilosia Meigen, 1822 \\ Cheilosia scutellata (FALLÉN, 1817)}

Material examined: West Azarbaijan province, Maku, $39^{\circ} 29^{\prime} \mathrm{N} 44.51^{\circ} \mathrm{E}, 2$ ㅇ , 2-3 July 2012.

Distribution outside Iran: Fennoscandia south to Iberia and round the Mediterranean to Greece, Turkey and North Africa; from Ireland eastwards through Eurasia to the Pacific coast.

\section{Genus Eristalinus RondANI, 1845}

\section{Eristalinus aeneus (SCOPOLI, 1763)}

Material examined: West Azarbaijan province, Khoy, $38^{\circ} 33^{\prime} \mathrm{N} 44^{\circ} 57^{\prime} \mathrm{E}, 10^{\top}$, 15-17 May 2012; Mahabad, 36 $46^{\circ} \mathrm{N}$

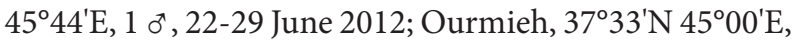
1 ㅇ , 3-5 August 2013.

Distribution outside Iran: Cosmopolitan; south to N Africa and the Canary Isles; Afrotropical region south to Kenya and Tanzania; southern Sweden; from Ireland eastwards through central and southern Europe and on through Russia and China to the Pacific and south into the Oriental region; Mauritius; in North America from Minnesota and Ontario south to California and Texas; Hawaii, Australia and the Gilbert and Ellis Islands in Australia; Bermuda.

\section{Eristalinus taeniops (WIEDEMANN, 1818)}

Material examined: West Azarbaijan province, Ourmieh, $37^{\circ} 33^{\prime} \mathrm{N} 45^{\circ} 00^{\prime} \mathrm{E}, 1$ ㅇ, 1 ○’, $3-5$ August 2013. 
Distribution outside Iran: Portugal, Spain and round the Mediterranean basin (southern France including Corsica, Italy, former Yugoslavia, Albania, Romania, Cyprus, Greece, Syria, Turkey, Lebanon, Israel, North Africa including Egypt, Libya, Tunisia, Morocco), Canary Islands, Transcaucasus; in eastern parts of the Afrotropical region down to South Africa and in Nepal and parts of Pakistan and northern India in the Oriental region.

\section{Genus Eristalis LATREILLE, 1804}

\section{Eristalis nemorum (LINNAEUS, 1758)}

Material examined: West Azarbaijan province, Mahabad, $36^{\circ} 46^{\prime} \mathrm{N} 45^{\circ} 44^{\prime} \mathrm{E}, 10^{\top}$, 22-26 June 2012; Salmas, $38^{\circ} 11^{\prime} \mathrm{N}$

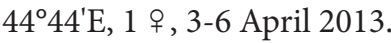

Distribution outside Iran: From Scandinavia to Spain, Italy, former Yugoslavia, Bulgaria; North European territory to Transcaucasus, Kazakhstan, Kyrgyzstan, West Siberia, Far East; Mongolia and Nearctic Region.

\section{Genus Eumerus MeIGEN, 1822}

\section{Eumerus sogdianus STACKELBERG, 1952}

Material examined: West Azarbaijan province, Oshnavieh, $37^{\circ} 03^{\prime} \mathrm{N} 45^{\circ} 05^{\prime} \mathrm{E}, 1$ ㅇ, 14 May 2013.

Distribution outside Iran: Denmark south to southern Spain; from Belgium eastwards through central and southern Europe into European parts of Russia and on into central Asia (Kazakhstan, Tajikistan, Uzbekistan, Mongolia); China.

\section{Eumerus strigatus (FALLEN, 1817)}

Material examined: West Azarbaijan province, Maku, $39^{\circ} 29^{\prime} \mathrm{N} 44.51^{\circ} \mathrm{E}, 1$ ㅇ, $10^{\circ}, 2-3$ July 2012.

Distribution outside Iran: Australia, Canada, Fennoscandia, Iberia and the Mediterranean, Japan, N America, New Zealand, Russia, Turkey.

\section{Genus Helophilus MeIgeN, 1822}

\section{Helophilus trivittatus (FABRICIUS, 1805)}

Material examined: West Azarbaijan province, Khoy, $38^{\circ} 33^{\prime} \mathrm{N} 44^{\circ} 57^{\prime} \mathrm{E}, 20^{\star}$, 15-17 May 2012.

Distribution outside Iran: From Fennoscandia south to the Mediterranean and from Ireland eastwards through Eurasia to the Pacific, Afghanistan.

\section{Genus Melanogaster RondanI, 1857}

Melanogaster hirtella (LoEW, 1843)

Material examined: West Azarbaijan province, Mahabad, $36^{\circ} 46^{\prime} \mathrm{N} 45^{\circ} 44^{\prime} \mathrm{E}, 2$ ㅇ , 22-29 June 2012.

Distribution outside Iran: Denmark south to the Pyrenees and Portugal; Ireland southwards to the Alps (Switzerland, Liechtenstein); United Kingdom.

\section{Genus Neoascia WiLLIston, 1886}

\section{Neoascia podagrica (FABRICIUS, 1775)}

Material examined: West Azarbaijan province, Mahabad, $36^{\circ} 46^{\prime} \mathrm{N} 45^{\circ} 44^{\prime} \mathrm{E}, 1$ 우, 22-29 June 2012.

Distribution outside Iran: From Fennoscandia south to Iberia and the Mediterranean, including Madeira, Cyprus and Crete; N Africa; from Ireland eastwards through northern, central and southern Europe (Italy, former Yugoslavia, Greece) to Turkey and Israel; European parts of Russia and western Siberia as far as Cis-Baikal.

\section{Genus Orthonevra MacouART, 1829}

Orthonevra brevicornis (LOEW, 1840)

Material examined: West Azarbaijan province, Ourmieh, $37^{\circ} 33^{\prime} \mathrm{N} 45^{\circ} 00^{\prime} \mathrm{E}, 1$ 우 , 7-11 June 2012.

Distribution outside Iran: Southern Finland and Denmark south to northern France (Brittany); from Britain (England) eastwards through parts of central Europe (Netherlands, Belgium, Germany, Poland) into European parts of Russia, the Caucasus and western Siberia.

\section{Genus Syritta Le Peletier et Serville, 1828}

\section{Syritta pipiens (LINNAEUS, 1758)}

Material examined: West Azarbaijan province, Oshnavieh, $37^{\circ} 03^{\prime} \mathrm{N} 45^{\circ} 05^{\prime} \mathrm{E}, 2$ 우, $10^{\star}, 14$ May 2013.

Distribution outside Iran: Cosmopolitan; known from most of the Palaearctic, including North Africa, most of North America, South America and the Oriental region. 


\section{Genus Tropidia MEIGEN, 1822}

Tropidia scita (HARRIS, 1780)

Material examined: West Azarbaijan province, Mahabad, $36^{\circ} 46^{\prime} \mathrm{N} 45^{\circ} 44^{\prime} \mathrm{E}, 1$ ㅇ , 22-29 June 2012.

Distribution outside Iran: From Fennoscandia south to central France; from Ireland eastwards through central Europe and on through Russia to the Caucasus and in Asia as far as the Pacific coast and Japan.

\section{Genus Volucella Geoffroy, 1762}

\section{Volucella inanis (LINNAEUS, 1758)}

Material examined: West Azarbaijan province, Oshnavieh, $37^{\circ} 03^{\prime} \mathrm{N} 45^{\circ} 05^{\prime} \mathrm{E}, 2$ ㅇ, $10^{*}$, 14 May 2013.

Distribution outside Iran: From southern Fennoscandia south to Spain and the Mediterranean (including islands, e.g. Crete), north Africa and Asia Minor (Syria); from Britain (southern England) eastwards through central and southern Europe into Turkey and European parts of Russia and through Siberia to the Pacific; Afghanistan, Mongolia, China.

\section{Volucella zonaria (PoDA, 1761)}

Material examined: West Azarbaijan province, Maku, $39^{\circ} 29^{\prime} \mathrm{N} 44.51^{\circ} \mathrm{E}, 1 \mathrm{o}^{\top}, 2-3$ July 2012 ; Salmas, $38^{\circ} 11^{\prime} \mathrm{N}$

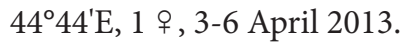

Distribution outside Iran: From Poland south to the Mediterranean (including islands, e.g. Crete) and North Africa; from Britain (southern England) eastwards through central and southern Europe (Italy, former Yugoslavia, Greece) into Turkey and European parts of Russia and through Siberia to the Pacific; Mongolia.

Subfamily Syrphinae

Genus Chrysotoxum MeIGEN, 1803

Chrysotoxum veralli ColuIn, 1940

Material examined: West Azarbaijan province, Salmas, $38^{\circ} 11^{\prime} \mathrm{N} 44^{\circ} 44^{\prime} \mathrm{E}, 1$ ㅇ , 3-6 April 2013.

Distribution outside Iran: Denmark south to central France; Britain (Wales and central/southern England) eastwards through central Europe into European parts of Russia to the Caucasus and eastern Siberia.

\section{Chrysotoxum elegans LoEW, 1841}

Material examined: West Azarbaijan province, Mahabad, $36^{\circ} 46^{\prime} \mathrm{N} 45^{\circ} 44^{\prime} \mathrm{E}, 1$ ㅇ , 1 o $^{\star}$, 22-29 June 2012.

Distribution outside Iran: Fennoscandia south to Iberia and the Mediterranean; through central and southern Europe into European parts of Russia as far as the Caucasus Mountains and into Turkey.

\section{Chrysotoxum octomaculatum CuRTIS, 1837}

Material examined: West Azarbaijan province, Miandoab, 365 $57^{\prime} \mathrm{N} 46^{\circ} 00^{\prime} \mathrm{E}, 20^{\star}$, 14-16 April 2013.

Distribution outside Iran: Britain (southern England) and Netherlands south to the Mediterranean and eastwards through central and southern Europe into southern parts of Russia to as far as Armenia and Kazakhstan.

\section{Chrysotoxum vernale LoEw, 1841}

Material examined: West Azarbaijan province, Khoy, $38^{\circ} 33^{\prime} \mathrm{N} 44^{\circ} 57^{\prime} \mathrm{E}, 10^{\star}, 15-17$ May 2012.

Distribution outside Iran: Fennoscandia south to the Pyrenees; from Britain (southern England) eastwards through most of Europe into Asia almost to the Pacific.

\section{Genus Dasysyrphus EnderLEIN, 1938}

\section{Dasysyrphus albostriatus (FALLÉN, 1817)}

Material examined: West Azarbaijan province, Ourmieh, $37^{\circ} 33^{\prime} \mathrm{N} 45^{\circ} 00^{\prime} \mathrm{E}, 2$ ㅇ , 3-5 August 2013.

Distribution outside Iran: Central Asia, North Africa; from Fennoscandia south to Iberia; from Ireland eastwards through central and southern Europe (Italy, former Yugoslavia) to Crete, Turkey and European parts of Russia (from the north to the Crimea and the Caucasus); Japan.

\section{Genus Episyrphus Matsumura et AdACHI, 1917}

\section{Episyrphus balteatus (DE GeER, 1776)}

Material examined: West Azarbaijan province, Miandoab, 36 $57^{\circ} \mathrm{N} 46^{\circ} 00^{\prime} \mathrm{E}, 1$ \%, $10^{*}, 14-16$ April 2013; Oshnavieh, $37^{\circ} 03^{\prime} \mathrm{N} 45^{\circ} 05^{\prime} \mathrm{E}, 1$ ㅇ, 14 May 2013; Ourm-

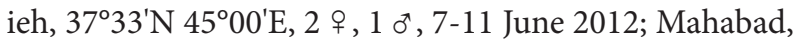
$36^{\circ} 46^{\prime} \mathrm{N} 45^{\circ} 44^{\prime} \mathrm{E}, 1$ ㅇ , 22-29 June 2012; Khoy, 38 33' $\mathrm{N}$ $44^{\circ} 57^{\prime} \mathrm{E}, 10^{\top}, 15-17$ May 2012; Salmas, $38^{\circ} 11^{\prime} \mathrm{N} 44^{\circ} 44^{\prime} \mathrm{E}$, 1 ค , 10 , 3-6 April 2013. 
Distribution outside Iran: Fennoscandia to the Mediterranean; Canary Isles, Azores and N Africa; Ireland through Eurasia to the Pacific coast; south through the Oriental region to Sri Lanka; Australia.

\section{Genus Eupeodes Osten SACKEN, 1877}

Eupeodes luniger (MEIGEN, 1822)

Material examined: West Azarbaijan province, Salmas, $38^{\circ} 11^{\prime} \mathrm{N} 44^{\circ} 44^{\prime} \mathrm{E}, 2$ ㅇ , 3-6 April 2013.

Distribution outside Iran: From Fennoscandia south to Iberia, the Mediterranean, Madeira and N Africa; from Ireland eastwards through most of Europe into European parts of Russia and Asia Minor (including Turkey); in Siberia from the Urals to the Pacific coast (Kuril Isles); Japan; India.

\section{Eupeodes nuba (WIEDEMANN, 1830)}

Material examined: West Azarbaijan province, Miandoab, 36 $57^{\prime} \mathrm{N} 46^{\circ} 00^{\prime} \mathrm{E}, 1$ ㅇ, $10^{\star}$, 14-16 April 2013.

Distribution outside Iran: Canary Isles, Mediterranean basin, from southern France to Italy and former Yugoslavia, Crete, Cyprus, Lebanon, Israel, Egypt and Morocco; Switzerland in central Europe, Romania; Transcausasus and south-western parts of Asia (Uzbekistan, Kyrgyzstan, Tajikistan) to Afghanistan and Mongolia. In eastern parts of the Afrotropical region from Ethiopia south to S Africa.

\section{Genus /schidon SACK, 1913}

$$
\text { Ischidon aegyptius (WIEDEMANN, 1830) }
$$

Material examined: West Azarbaijan province, Oshnavieh, $37^{\circ} 03^{\prime} \mathrm{N} 45^{\circ} 05^{\prime} \mathrm{E}, 1$ ㅇ, 14 May 2013.

Distribution outside Iran: Throughout the Afrotropical region and into $\mathrm{N}$ Africa to the coast of the Mediterranean and Yemen; southern Spain, southern Italy, the Balearic Islands and the Canaries.

\section{Genus Melanostoma SCHINER, 1860}

\section{Melanostoma mellinum (LINNAEUS, 1758)}

Material examined: West Azarbaijan province, Miandoab, 365ำ $\mathrm{N} 46^{\circ} 00^{\prime} \mathrm{E}, 1$ ㅇ , 14-16 April 2013.

Distribution outside Iran: From Iceland and Fennoscandia south to Iberia, the Mediterranean and North Africa; from Ireland eastwards through most of Europe into European parts of Russia; Siberia from the Urals to the Pacific coast; North America from Alaska to Quebec and south to Washington.

\section{Genus Paragus LATREILLE, 1804}

Paragus (Pandasyophtalmus) abrogans GoELDLIN, 1971

Material examined: West Azarbaijan province, Ourmieh, $37^{\circ} 33^{\prime} \mathrm{N} 45^{\circ} 00^{\prime} \mathrm{E}, 2$ , 7-11 June 2012.

Distribution outside Iran: Greece, Kyrgyzstan, Tajikistan, Turkey, Turkmenistan, Uzbekistan.

\section{Paragus (Paragus) albifrons (FalléN, 1817)}

Material examined: West Azarbaijan province, Ourmieh, $37^{\circ} 33^{\prime} \mathrm{N} 45^{\circ} 00^{\prime} \mathrm{E}, 10^{\star}, 7-11$ June 2012.

Distribution outside Iran: From southern Norway and Denmark south to the Mediterranean; from Britain (southern England) eastwards through central and southern Europe (Italy, the former Yugoslavia, Bulgaria) into European parts of Russia and the Caucasus and on to the Pacific; Afghanistan and Mongolia, Turkey.

\section{Paragus (Paragus) bicolor FABRicIus, 1794}

Material examined: West Azarbaijan province, Miandoab, 365 $57^{\prime} \mathrm{N} 46^{\circ} 00^{\prime} \mathrm{E}, 1$ ㅇ , 2 o', 14-16 April 2013.

Distribution outside Iran: Afghanistan, Denmark, France, Kazakhstan, Kirghizia, Mongolia, North America, Russia, south to the Mediterranean, Sweden, North Africa, Tajikistan, Turkmenistan.

\section{Paragus (Paragus) compeditus (WIedemann, 1830)}

Material examined: West Azarbaijan province, Ourmieh, $37^{\circ} 33^{\prime} \mathrm{N} 45^{\circ} 00^{\prime} \mathrm{E}, 2$ ㅇ , 7-11 June 2012.

Distribution outside Iran: Asiatic Russia, China, Cyprus, Italy, Kazakhstan, Kyrgyzstan, Middle East, North Africa, Tajikistan, Turkey, Ukraine, Uzbekistan.

\section{Paragus (Paragus) pecchiolii Rondanı, 1857}

Material examined: West Azarbaijan province, Salmas, $38^{\circ} 11^{\prime} \mathrm{N} 44^{\circ} 44^{\prime} \mathrm{E}, 1$ ㅇ , 1 o $^{\star}$, 3-6 April 2013.

Distribution outside Iran: Austria, Czech Republic, Denmark, European parts of Russia, France, Germany, 
Liechtenstein, Mediterranean Islands, North Africa, Norway, Romania, Spain, Switzerland, Turkey, former Yugoslavia.

\section{Genus Scaeva FABRICIUS, 1850}

\section{Scaeva albomaculata (MacouarT, 1842)}

Material examined: West Azarbaijan province, Khoy, $38^{\circ} 33^{\prime} \mathrm{N} 44^{\circ} 57^{\prime} \mathrm{E}, 1$ ㅇ , 15-17 May 2012.

Distribution outside Iran: Afghanistan, Canary Islands, Caucasus, China, Iberian Peninsula, Mediterranean basin to Morocco, Mongolia, Russia, Siberia, UK.

\section{Scaeva dignota RóNDANI, 1857}

Material examined: West Azarbaijan province, Oshnavieh, $37^{\circ} 03^{\prime} \mathrm{N} 45^{\circ} 05^{\prime} \mathrm{E}, 2$ ㅇ, 14 May 2013.

Distribution outside Iran: Austria, Belgium, Brittany, Czech Republic, Denmark, Sweden, France, Germany, Greece, northern Africa, Portugal, Spain, Switzerland, Turkey, former Yugoslavia.

\section{Genus Sphaerophoria Le Peletier et ServiLle, 1828}

\section{Sphaerophoria rueppellii (WIEDEMANN, 1830)}

Material examined: West Azarbaijan province, Salmas, $38^{\circ} 11^{\prime} \mathrm{N} 44^{\circ} 44^{\prime} \mathrm{E}, 10^{\circ}$, 3-6 April 2013.

Distribution outside Iran: From southern Norway and Sweden south to North Africa and the Canary Isles; from Ireland east through central and southern Europe, including Greece, Turkey and Mediterranean islands into Asia Minor, Russia and Afghanistan and on to the Pacific coast, China and Korea; in eastern parts of the Afrotropical region south to Kenya.

\section{Sphaerophoria scripta (LINNAEUS, 1758)}

Material examined: West Azarbaijan province, Mahabad, $36^{\circ} 46^{\prime} \mathrm{N} 45^{\circ} 44^{\prime} \mathrm{E}, 1$ 우 , $10^{\star}$, 22-29 June 2012.

Distribution outside Iran: A highly migratory species; southwest Greenland, Iceland and Fennoscandia south to the Mediterranean, the Canary Isles and N Africa; from Ireland eastwards through much of the Palaearctic to the Pacific coast of Asia; Kashmir and Nepal.

\section{Genus Syrphus FabRICIUS, 1775}

Syrphus ribesii (LINNAEUs, 1758)

Material examined: West Azarbaijan province, Khoy, $38^{\circ} 33^{\prime} \mathrm{N} 44^{\circ} 57^{\prime} \mathrm{E}, 1$ ㅇ , $10^{\star}$, 15-17 May 2012; Miandoab, $36^{\circ} 57^{\prime} \mathrm{N} 46^{\circ} 00^{\prime} \mathrm{E}, 1$ ㅇ , 14-16 April 2013.

Distribution outside Iran: From Iceland and Fennoscandia south to Iberia and the Mediterranean; Canary Isles; from Ireland eastwards through most of Europe into Turkey, European parts of Russia and Afghanistan; from the Urals to the Pacific coast (Kuril Isles); Japan; North America from Alaska south to central parts of the USA.

\section{Discussion}

The results of this research indicate that there is a diverse fauna of Syrphidae in West Azarbaijan province, and of course we expect that some other species remain to be discovered. To find new species and distributional records, more studies should be conducted on this important insect group in West Azarbaijan province. Among the collected species, Episyrphus balteatus is widely distributed and occurring in most of the sampled regions. The larva of many species of hoverflies, particularly subfamily Syrphinae are efficient predators of aphids and other agricultural pests which can play important role in biological control (Gilbert 1981; Müller \& Godfrey 1999). Therefore the faunistic surveys on these beneficial insects must be continued in order to determine the species diversity of syrphids in the mentioned province and also other areas of Iran.

\section{Acknowledgements}

The authors are warmly thanks to R. Hayat (Turkey), J. Bennewicz (Poland), and A. Jabbari (Iran) for their valuable helps in progress of this project. The research was supported by Young Researchers and Elite Club, Qaemshahr Islamic Azad University, and Bydgoszcz University of Technology and Life Sciences.

\section{References}

Alichi, M.; Asadi, G. H. \& Gharali, B. 2002: Aphidophagus syrphids of Fars province. Proceedings of $14^{\text {th }}$ Iranian Plant Protection Congress: p. 181.

Bedoreh, M.; Ghajariyeh, H. \& Gharali, B. 2008: Survey of hoverflies (Diptera: Syrphidae) in Ilam. Proceedings of $18^{\text {th }}$ Iranian Plant Protection Congress: p. 107. 


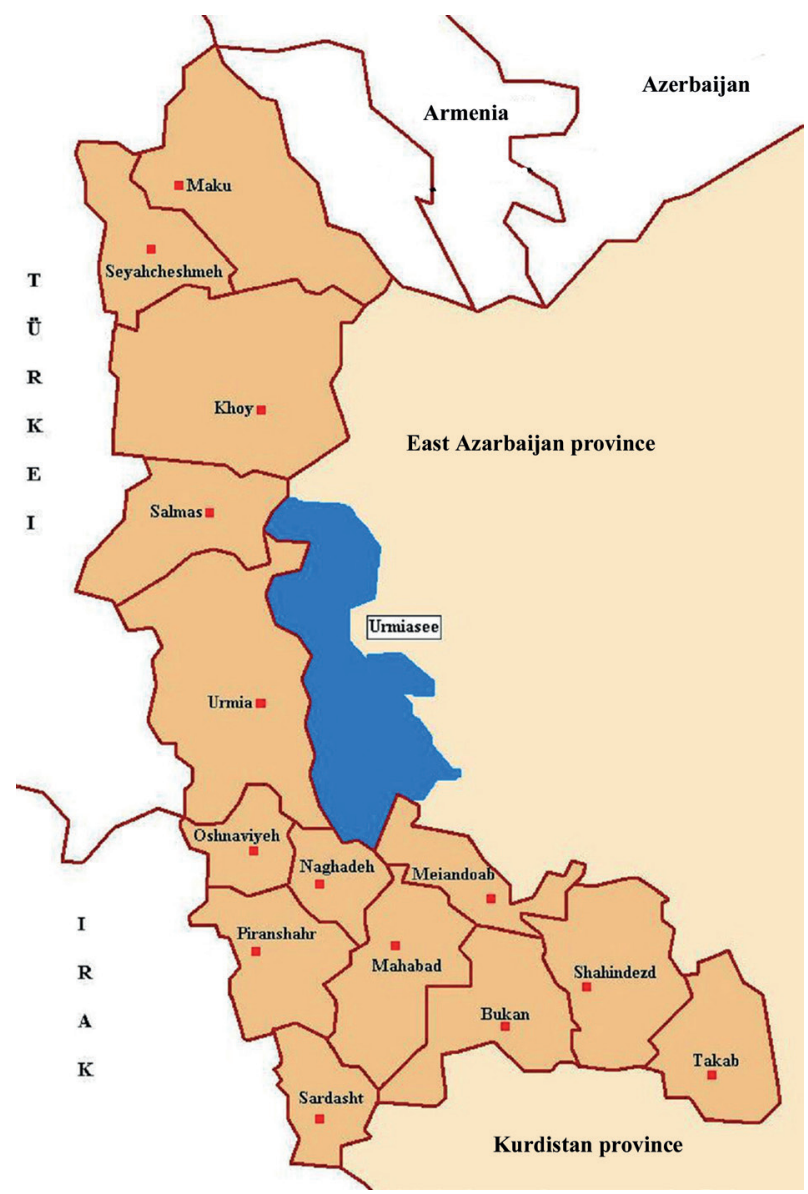

Fig. 1: West Azarbaijan province and its cities.

Bedoreh, M. \& Ansari Pour, A. 2012: Study of Syrphid fly in Ilam province and the first report of Merodon hirtus (HuRKMANs, 1993) for Iranian fauna. - Life Science Journal 9 (3): 900-904.

Bei-Bienko, G. 1988: Keys to the insects of the European part of the USSR. Volume V. Diptera and Siphonaptera. Part II. - Smithonian Institution Libraries and the National Science Foundation Washington, D.C.: pp. 10-148.

BenNEwiCZ, J. 2011: Aphidivorous hoverflies (Diptera: Syrphidae) at field boundaries and woodland edges in an agricultural landscape. - Polish Journal of Entomology 80: 129-149.

Bezzi, M. 1966: The Syrphidae of the Ethiopian region. Johnson reprint Corporation. - Printed in the U.S.A.: $146 \mathrm{pp}$.

Brown, M. W. 2004: Role of aphid predator guild in controlling spirea aphid populations on apple in West Virginia, USA. - Biological Control 29: 189-198.

BugG, R. L. 1993: Habitat manipulation to enhance the effectiveness of aphidophagous hover flies (Diptera: Syrphidae). - Sustainable Agriculture and Technical Revue 5: 12-15.

Candemir, D. \& KarA, K. 2003: Syrphidae (Diptera) fauna in Tokat provinces (Turkey). - Türkiye Entomoloji Dergisi 27 (2): 95-105.
Dousti, A. F. 1999: Fauna and Diversity of Syrphid flies in Ahwaz region. - M. Sc. thesis of Entomology, Shahid-Chamran University: 129 pp.

Dousti, A. F. \& Hayat, R. 2006: A catalogue of the Syrphidae (Insecta: Diptera) of Iran. - Journal of Entomology Research Society 8 (3): 5-38.

Ehteshamnia, N.; Khaghaninia, S. \& FarshbaF Pour-Abad, R. 2010: Some hoverflies of subfamily Syrphinae of Qurigol fauna in East Azerbayjan province, Iran (Diptera: Syrphidae). - Munis Entomology \& Zoology 5 (2): 499-505.

FAegri, K. \& VAN Der PiJL, L. 1979: The principles of pollination ecology. - Pergamon, Oxford, England: $244 \mathrm{pp}$.

Frank, T. 1999: Density of adult hoverflies (Dipt., Syrphidae) in sown weed strips and adjacent fields. Journal of Applied Entomology 123: 351-355.

Ghahari, H.; Hayat, R.; TAbari, M. \& Ostovan, H. 2008a: Hover flies (Diptera: Syrphidae) from rice fields and around grasslands of Northern Iran. Munis Entomology \& Zoology 3 (1): 275-284.

Ghahari, H.; Hayat, R.; Chao, C.-M. \& Ostovan, H. 2008b: A contribution to the dipteran parasitoids and predators in the Iranian cotton fields and surrounding grasslands. - Munis Entomology \& Zoology 3 (2): 699-706.

Gharali, B.; Alichi, M. \& Radjabi, G. R. 2000: The new records of syrphidflies (Dip.: Syrphidae). - Proceeding of the $14^{\text {th }}$ Iranian Plant Protection Congress: p. 348.

Gharali, B. \& Reemer, M. 2014: First record of the genus Milesia (Dip.: Syrphidae: Eristalinae) from Iran. - Journal of Entomological Society of Iran 34 (2): 41-42.

Gilasian, E. 2005: New record of one genus and six species of Syrphidae (Diptera) from Iran. - Journal of Entomological Society of Iran 25 (1): 75-76.

Gilasian, E. \& Sorokina, V. S. 2011: The genus Paragus LATreille (Diptera: Syrphidae) in Iran, with the description of a new species. - Zootaxa 2764: 49-60.

Goldasteh, Sh.; Bayat Asadi, H.; Shojaee, M. \& Baniameri, V. A. 2002: A faunistic survey of Syrphidae (Diptera) in Gorgan region. - Proceeding of the $15^{\text {th }}$ Iranian Plant Protection Congress: p. 168.

Golmohammadi, GH. \& Khiaban, N. 2004: Hoverflies (Diptera: Syrphidae) fauna of wheat fields in Sistan region. - Proceedings of $16^{\text {th }}$ Iranian Plant Protection Congress: p. 132.

Hosseini, M. \& SADEghi, H. 2008: Diversity of Syrphidae (Diptera) in agroecosystems of Neyshabor region. Journal of Plant Protection (Agricultural Science \& Technology) 22 (2): 85-93.

Hosseini, C. \& Khaghaninia, S. 2014: Study of the tribe Syrphini (Diptera: Syrphidae) with a new record from the Saqqez region, Iran. - Calodema 336: 1-5.

Hosseini, C. \& Khaghaninia, S. 2015: Study of the tribe Pipizini (Diptera: Syrphidae) in Saqqez region-Iran. Entomofauna 36: 221-228. 
JABBARI, A. 2011: Species diversity of hover flies (Diptera: Syrphidae) and determination of dominant species in Garmsar region. - M. Sc thesis of Entomology, Islamic Azad University, Science and Research Branch.

Kamangar, S.; Mansour Ghazi, M. \& Gharali, B. 2004: Identification of syrphid flies in wheat fields, and a survey on population fluctuations of the dominant species in Kurdistan province. - Proceeding of the $16^{\text {th }}$ Iranian Plant Protection Congress: p. 144.

Kamangar, S.; Gharali, B. \& Mansour Ghazi, M. 2006: Hoverflies (Dip.: Syrphidae) fauna on alfalfa in Kurdistan province. - Proceeding of the $17^{\text {th }}$ Iranian Plant Protection Congress: p. 68.

Kazerani, F.; Talebi, A. A. \& Gilasian, E. 2012: Faunistic study of the subfamily Milesiinae (Diptera: Syrphidae) in Saqqez, west of Iran. - Journal of Crop Protection 1 (4): 287-291.

Kazerani, F.; Talebi, A. A. \& Gilasian, E. 2013: An annotated checklist of the subfamily Syrphinae (Diptera: Syrphidae) of Iran. - Entomofauna 34: 517-556.

Kevan, P. G. \& BAKER, H. G. 1983: Insects as flower visitors and pollinators. - Annual Review of Entomology 28: 407-453.

Khaghaninia, S. 2010: Faunistic study on flower flies of Zunuz region in East Azerbayjan province-Iran (Diptera; Syrphidae). - Munis Entomology \& Zoology 5 (2): 586-593.

Khaghaninia, S.; Jafarlu, M.; Khiaban, N. G. \& ASKARI, O. 2010a: Introduction to hover flies (Diptera: Syrphidae) of sunflower and pumpkin fields in West Azerbayjan province-Iran. - Munis Entomology \& Zoology 5 (1): 270-277.

Khaghaninia, S.; Pour Abad, R. F. \& Hayat, R. 2010b: Seven species as new records for hover flies fauna of Iran (Diptera, Syrphidae) from Qaradag Forests. Munis Entomology \& Zoology 5 (1): 307-308.

Khaghaninia, S.; Saribiyik, S. \& Khiaban, N. G. M. Z. 2010c: A new record for Iran flower fly fauna, Baccha elongata (FABRICIUS, 1775) (Diptera: Syrphidae). - Munis Entomology \& Zoology 5, supplement: 900-903.

Khaghaninia, S.; Pour Abad, R. F. \& Ehteshamnia, N. 2010d: Some of hoverflies fauna of subfamily Milesiinae (Diptera: Syrphidae) of Qurigol in East Azerbayjan province, Northwest Iran. - Munis Entomology \& Zoology 5, supplement: pp. 911-916.

Khaghaninia, S. 2011: Flower flies of Isperekhan Valley with the first record of Chalcosyrphus CuRRAN, 1925 from Iran (Diptera: Syrphidae). - Munis Entomology \& Zoology 6 (1): 436-445.

Khaghaninia, S.; Pour Abad, R. F. \& SARibiyik, S. 2011: A genus with two species as new records for Iranian hover fly fauna (Diptera: Syrphidae). - Munis Entomology \& Zoology 6 (1): 317-320.
Khaghaninia, S. \& Shakeryari, A. 2012: Two species as new records for Iranian hover flies of the genus Pipizella Rondani, 1856 from East Azerbayjan province, Iran. - Munis Entomology \& Zoology 7 (2): 983-987.

Khaghaninia, S.; Shakeryari, A. \& Gharaei, B. 2012a: Synopsis of the genus Chrysogaster Loew, 1857 (Diptera: Syrphidae) in Iran. - Munis Entomology \& Zoology 7 (1): 363-367.

Khaghaninia, S.; Vosughian, M. \& Kazerarani, F. 2012b: Faunistic study of the genus Cheilosia Meigen, 1822 (Diptera: Syrphidae) in the south-eastern valleys of the Sahand mountain chain, East Azerbaijan province, Iran. - Calodema 238: 1-6.

Khaghaninia, S. \& Hosseini, C. 2013: Taxonomic study of Paragus Latreille (Diptera: Syrphidae) in the East Azerbaijan and Kordestan provinces of Iran. Efflatounia 13: 8-18.

Khaghaninia, S. 2014: Additional notes on the subfamily Syrphinae (Diptera: Syrphidae) from Qaradagh Forests in East Azerbaijan province, Iran. - Calodema 318: $1-5$.

Khaghaninia, S.; Shakeryari, A. \& Hayat, R. 2014: First record of two genera of hoverflies (Diptera: Syrphidae) from East Azerbaijan Province, Iran. Entomofauna 35: 21-28.

Khaghaninia, S. \& Kazerani, F. 2014: Study of the family Syrphidae from the Xumarlu region with one species as a new record for Iran. - Calodema 331: $1-6$.

Khiaban, N. G.; Hayat, R.; Safaralizadeh, M. \& PARCHAMI, M. 1998: A faunistic survey of Syrphidae in Uromieh region. - Proceeding of the $13^{\text {th }}$ Iranian Plant Protection Congress: p. 231.

Khiaban, N. G. \& ADIM, H. 2002: Introduction of Eumerus sogdianus StaK (Dip.: Syrphidae) on broomrape from Iran. - Proceeding of the $15^{\text {th }}$ Iranian Plant Protection Congress: p. 207.

Khosravian, Z.; SAdeghi, H. \& Ssymank, A. 2015: Hover-flies (Diptera: Syrphidae) of Kerman province, Iran. - Far East Entomologist Number 290: 1-12.

Lyneborg, L. \& BARKemeyer, W. 2005: The genus Syritta: A world revision of the genus Syritta. Volume 15. - Apollo Books Publication, Stenstrup: 224 pp.

Mengual, X.; Kazerani, F; Talebi, A. A. \& Gilasian, E. 2015: A revision of the genus Pelecocera MeIgen with the description of the male of Pelecocera persiana KuzNETzov from Iran (Diptera: Syrphidae). - Zootaxa 3947 (1): 99-108.

Motamedi Nia, B. \& Wyatt, N. 2006: Syrphid fly (Syrphidae: Diptera) in Baluchestan. - Proceeding of the $17^{\text {th }}$ Iranian Plant Protection Congress: p. 69.

Modarres Awal, M. 1997: Family Syrphidae, pp. 253-254. - In: Modarres Awal, M. (ed.): List of agricultural pests and their natural enemies in Iran. Ferdowsi University Press: 429 pp. 
Mohammadi, D. \& Khaghaninia, S. 2013: Faunistic study on the hover flies (Diptera: Syrphidae) of the Meshkin Shahr region in the north-west of Iran. Calodema 263: 1-7.

Müller, C. B. \& Godfrey, H. C. J. 1999: Predators and mutualists influence the exclusion of aphid species from natural communities. - Oecologia 119: 120-125.

Naderloo, M.; Pashaei Rad, Sh. \& Taghaddosi, M. V. 2011: Faunistic study on hover flies (Diptera: Syrphidae) in the eastern part of Zanjan province, Iran. - Journal of Entomological Research 4 (4): 313-323.

Olszak, R. W. 1999: Consideration of biological factors limiting the numbers of aphids in fruit cultures. Aphids and Other Hemipterous Insects 7: 277-287.

Papp, L. \& DARvas, B. 1997, 1998, 2000: Contributions to a Manual of Palearctic Diptera. Vol. I: 2000 (978 pp.), Vol. II: 1998 (592 pp.), Vol. III: 1997 (880 pp.). Science Heraid, Budapest.

Pashae Rad, Sh.; Pourrab, S. R. \& Lotfalizadeh, H. 2002: Syrphid flies, Eristalinae (Dip.: Syrphidae) in Marand, Northwest of Iran. - Proceeding of the $15^{\text {th }}$ Iranian Plant Protection Congress, p. 167.

Peck, L. V. 1988: Family Syrphidae, pp. 11-230. - In: Soos, A. (ed.): Catalogue of Palearctic Diptera. - Akademiai Kiado, Budapest, Vol. 8: 363 pp.

SADEghI, H. 2003: A check list of Iranian hover flies (Diptera: Syrphidae). II. International Symposium on the Syrphidae. - Biodiversity and Conservation, 16-19 ${ }^{\text {th }}$ June 2003, Alicante, Spain: p. 41.

SADEGHI, H. 2008. Abundance of adult hoverflies (Diptera: Syrphidae) on different flowering plants. - Caspian Journal of Environmental Science 6 (1): 47-51.

Sadeghi, H.; Kayvanfar, N. \& Mojtahedzadeh, K. 2002: Hover flies (Dip.: Syrphidae) fauna of Mashhad region. - Proceeding of the $15^{\text {th }}$ Iranian Plant Protection Congress: p. 169.

Sakenin Chelav, H.; Raheb, J.; Imani, S.; HavasKARY, M.; Shirdel, F. \& Mohseni, H. 2008: A preliminary survey on dipteran predators and parasitoids and Odonata in Iranian rice fields. Proceedings of National Conference of Agronomical Rice Breeding, Islamic Azad University of Ghaemshahr, p. 79 (Full paper in CD Rom, 14 pp.) (In Persian with English Summary).
Shakeryari, A. \& Khaghaninia, S. 2012: Some of flower flies fauna of the Milesiinae subfamily (Diptera: Syrphidae) of Gunber region in East Azarbaijan province including a key for the genera. - Munis Entomology \& Zoology 7 (2): 1111-1115.

Shakeryari, A.; Khaghaninia, S. \& Irani Nejad, K. H. 2012: Four species as new records of tribe Chrysogasterini (Diptera: Syrphidae) from Iran. Munis Entomology \& Zoology 7 (1): 385-390.

Simic, S. \& GlumaC, S. 1987: The Syrphid fauna of Montenegro (Insecta: Diptera): A zoogeographical analysis within the Balkan Peninsula. Biologia Gallohellenica, Kammena Vourla 13: 99-102.

Speight, M. C. D. 2011: Species accounts of European Syrphidae (Diptera). - In: Speight, M. C. D.; Castella, E.; Sarthou, J.-P. \& Monteil, C. (eds): Syrph the Net, the database of European Syrphidae. Syrph the Net Publication, Dublin, Vol. 65: 285 pp.

Ssymank, A.; Kearns, C. A.; Pape, T. \& Thompson, C. 2008: Pollinating flies (Diptera): A major contribution to plant diversity and agricultural production. Tropical Conservancy, Biodiversity 9 (1 \& 2): 86-89.

StubBs, A. E. \& Falk, S. J. 2002: British hover flies. An illustrated identification guide. Pub. - The British Entomology and Natural History Society, Reading, UK: 467 pp.

van Veen, M. 2004: Hoverflies of Northwest Europe: identification keys to the Syrphidae. - KNNV Publishing, Utrecht: 256 pp.

Vosughian, M.; Khaghaninia, S. \& Irani Nejad, H. 2013: Hover-fly fauna of the subfamily Syrphinae (Diptera: Syrphidae) of Maragheh region, Iran, with a new record for the Iranian insect fauna. - Calodema 274: $1-6$ 